\title{
PEWARNAAN KAIN IKAT CELUP MENGGUNAKAN BAHAN ALAMI DAUN JAMBU BIJI (PSIDIUM GUAJAVAL) DI SANGGAR SENI PENDOPO
}

\author{
Ebid $^{1 *}$, Wahyu Tri Atmojo ${ }^{2 *}$ \\ Program Studi Pendidikan Seni Rupa Jurusan Seni Rupa Fakultas Bahasa dan Seni \\ Universitas Negeri Medan \\ Jl. Willem Iskandar Pasar V Medan Estate, Kec, Percut Sei Tuan, Kab. Deli Serdang, Kode Pos 20371 \\ Sumatera Utara. Indonesia \\ Email: ebidirwansyah@gmail.com,wahyu3mojo@yahoo.com
}

\begin{abstract}
Abstrak
Penelitian ini bertujuan untuk "Mendeskripsikan Proses Dan Menganalisis Hasil Pewarna Daun Jambu Biji Terhadap Kain Ikat Celup". Metode penelitian yang digunakan adalah eksperimen untuk mencari pengaruh perlakuan tertentu terhadap yang lain dalam kondisi yang terkendali. Eksperimen dalam penelitian untuk mengetahui besarnya pengaruh lamanya perendaman kain dalam larutan pewarna daun jambu biji terhadap hasil pencelupan pewarna pada kain blacu.Instrument ini dijaring memalui perlakuan yaitu pembuatan kain ikat celup dengan teknik ikat celup menggunakan pewarna alami yaitu daun jambu biji yang diamati beberapa waktu tertentu, dengan demikian dapat dirtikan bahwa butir butir komponen tentang hasil warna ragam hias teknik ikat celup melalui pewarna daun jambu biji dapat digunakan untuk menjaring data penelitian. Hasil penelitian yang dilakukan menggunakan pengamatan secara visual, hasil yang diperoleh pada selama 1 jam, 2 jam, 3 jam perendaman larutan daun jambu biji dan perendaman kain selama 2 jam, 4 jam, 6 jam di setiap rendaman larutan daun jambu biji bahwa terdapat hasil warna yang signifikan pada teknik ikat celup, terdapat pengaruh perbedaan warna pada perendaman daun jambu biji pada teknik ikat celup dan warna yang dihasilkan beragam, mulai dari hijau muda hingga gijau kecokelatan dan hasil motif berbentuk lebih terang dan jelas, berbentuk motif baru pada dasar kain pada perendaman yang paling lama.
\end{abstract}

Kata Kunci: pewarna, daun, kain.

\begin{abstract}
This study aims to "describe the process and analyze the results of guava leaf dye on the tie dye." The research method used was an experiment to find the effect of certain treatments on others under controlled conditions. Experiments in this study were to determine the effect of the length of soaking the cloth in a guava leaf dye solution on the dyeing results of the calico cloth. This instrument was netted through treatment, namely the manufacture of tie-dyed fabric using natural dyes, namely guava leaves which were observed for a certain time. , thus it can be concluded that the component items regarding the color yield of the decorative variety, the tie-dye technique through guava leaf dye, can be used to capture research data.The results of the research were carried out using visual observation, the results obtained for 1 hour, 2 hours, 3 hours of soaking guava leaf solution and soaking the cloth for 2 hours, 4 hours, 6 hours in each soaking guava leaf solution that there is a color result. There is a significant effect on the tie-dye technique, there is an effect of different colors on the immersion of guava leaves in the tie-dye technique and the resulting color varies, from light green to brownish green and the resulting motifs are lighter and clearer, in the form of new motifs on the base of the cloth on soaking the longest.
\end{abstract}

Keywords: dye, leaves, cloth..

\section{PENDAHULUAN}

Kain ikat celup merupakan salah satu kerajinan yang mempunyai nilai seni tinggi dan menjadi budaya Indonesia yang terkenal sampai ke berbagai negara. Diantara berbagai jenis kain, kain ikat celup alam merupakan jenis kain yang berkualitas tinggi. Hal itu dikarenakan kain ikat celup alam di produksi dengan pewarna alami dan memberikan motif dan kesan tersendiri, sebab pewarna alami ramah lingkungan dan aman untuk kesehatan karena zat-zat yang terkandung dalam pewarna alami dapat dengan mudah terurai sehingga tidak menimbulkan polusi.

Dengan kemajuan teknologi di dunia khususnya di Indonesia membuat pemakaian warna alam berkurang, dikarenakan keterbatasan pengetahuan ten tang warna alam itu sendiri. Kebanyakan orang lebih memilih memakai warna sintetik dikarenakan bahannya yang mudah didapat.Pewarna sintetis memiliki dampak negatif yang tinggi terhadap 
lingkungan dan manusia, terutama yang terlibat dalam proses manufaktur dan penggunanya. Peningkatan kesadaran bahaya lingkungan dan kesehatan yang terkait dengan sintesis, pengolahan dan penggunaan pewarna sintetis telah menciptakan minat dalam pembuatan pewarna alami untuk tekstil. Ini didorong karena sumber-sumber alami zat pewarna seperti dari tumbuhan, serangga, mineral dan jamur berlimpah.

Warna alam memang memiliki karakteristik warna yang tergolongtidak cerahseperti warna-warna kayu, lain hal nya dengan warna sintetik yang dapat menghasilkanwarna yang beragam. Nah peneliti melakukan eksperimen di salah satu sanggar seni yang nantinya dapat membantu peneliti untuk mengumpulkan beberapa data dan informasi terkait dengan yang akan diteliti. Sebelum melakukan penelitian, peneliti melakukan observasi ke sanggar guna untuk megumpulkan beberapa data. Peneleiti melakukan eksperimen di Sanggar Seni Pendopo yang beralamat di Jl. Terusan Perumahan Ray Pendopo No.03 Kec. Percut Sei Tuan Kab. Deli Serdang. Perkembangan penggunaan pewarna alami sebagai pewarna tekstil belakangan ini meningkat. Hal ini terkait dengan standar lingkungan dan larangan penggunaan pewarna sintetis. Seperti di Jerman dan Belanda yang mensyaratkan penggunaan bahan pewarna tekstil yang ramah lingkungan dan tidak menghendaki pemakaian pewarna sintetis.

Warna alam ini lebih ramah lingkungan karena tidak menghasilkanlimbah yang berbahaya bagi makhluk hidup.Warna alam dapat dihasilkan dari batang,daun, buah, dan akar. Kali ini peneliti akan membahaswarna alam yang dihasilkan dari daun,yaitu menggunakan daun jambu biji (Psidium guajava). Daun jambu biji selain dapat digunakan sebagai obat herbal juga dapat digunakan sebagai bahan pewarna alami tekstil.Daun jambu biji (Psidium guajava L.) berbau aromatik dan rasanya sepat. Daunnya merupakan daun tunggal yang berwarna hijau keabuan, helai-helai daun berbentuk jorong sampai bulat memanjang, ujung daunnya meruncing sedangkan pangkal daunnya juga meruncing tetapi ada pula yang membulat, daun berukuran panjang antara $6 \mathrm{~cm}$ sampai $15 \mathrm{~cm}$ dan lebar antara $3 \mathrm{~cm}$ sampai $7,5 \mathrm{~cm}$ sedangkan tangkainya kurang lebih $1 \mathrm{~cm}$. Daun berambut penutup pendek, tampak berbintik-bintik yang sesungguhnya merupakan rongga-rongga lisigen, warnanya gelap namun biladalam keadaan terendam air menjadi tembus cahaya
Gorga : Jurnal Seni Rupa

Volume 09 Nomor 02 Juli-Desember 2020

p-ISSN: 2301-5942 | e-ISSN: 2580-2380

Pemanfaatan bahan alami lokal seperta daun Jambu Biji (Psidium guajava) sebagai bahan utama pewarnaan kain ikat celup, kita dapat memanfaatkan hasil bumi lokal dengan baik, selain itu para pengerajin kain daerah lokal maupun yang lainnya tidak lagi kesulitan untuk mendapatkan zat pewarna yang merupakan suatu bahan yang sangat penting dalam penciptaan kain ikat celup.

\section{KAJIAN TEORI}

\section{Pengertian Kain Ikat Celup}

Kain ikat celup atau jumputan adalah kain yang dikerjakan dengan cara di ikat celup, diikat dengan tali dicelup dengan warna. Kata jumputan diambil dari bahasa Jawa yang artinya memungut atau mengambil dengan semua ujung jari tangan, cara pembuatan kain jumputan sangat sederhana dan mudah dilakukan karena tidak menggunakan lilin dan canting.

Kain ikat celup dikenal dengan nama jumputan atau tritik yang salah satu teknik menghias di atas permukaan kain. Secara tradisional kain jumputan diguanakan sebagai selendang, penutup dada atau kemben bagi gadis atau juga sebagai pelengkap kain bawahan. Namun kali ini sempat dikembangkan lebih jauh oleh kalangan desainer, sehingga sekarang ini dapat dikatakan membanjiri pasar dalam aneka ragam bentuk, seperti kemeja, gaun, bahan busana serta pelengkap rumah tangga. Bahkan kain jumputan kini juga sudah mendapat tempat sebagai salah satu busana resmi indonesia.

\section{1). Macam-Macam Ikatan}

(1). Ikat mawar dapat digunakan untuk membuat pola lingkaran.Cara membuatnya dengan menjumput kain kemudian mengikat bagian dasar jumputan dengan tali karet. Garis tengah lingkaran yang akan terbentuk dua kali tinggi jumputan kain. (2). Ikat mawar berbelit. Cara membuat ikat mawar berbelit kurang lebih hampir sama dengan membuat ikat mawar. Sete;ah bagian dasarnya terikat selanjutnya teruskan dengan membuat ikatan spiral menuju puncak jumputan. Bila ingin membuat pola yang lebih rumit lagi, buatlah tali yang lebih banyak. (3). Ikatan donat merupakan jenis ikatan yang biasa digunakan untuk membentuk pola desain lingkaran berlapis.Cara paling mudah membuat ikatan donat ini yaitu jumput kain sesuai kebutuhan kemudian pegang bagian dasar kain dengan tangan kiri.Tekan bajian ujung jumputan ke arah bawah kemudian ikat. (4). Ikatan garis dapat dibuat dengan cara membuat beberapa buah garis bantu pada kainmenggunakan kapur atau pensil. Selesai digaris selanjutnya kain dilipat menurut garis dan diikat kuat - kuat.Untuk membuat beberapa garis, tariklah beberapa garis 
pedoman. (5). Ikatan pengerutan dapat dimanfaatkan untuk menghasilkan desain pola yang menyerupai marmer. Pola marmer dibuat dengan cara mengerutkan kain secara tidak teratur. Ikat kain kuat - kuat agar kerutan tidak lepas. Bila ikatannya kuat, akan menghasilkan motif ceplok - ceplok putih. (6). Ikatan benda. Pola ini dibuat dengan mengikat benda yang ukurannya seragam.Contohnya kelereng yang diikat dengan teknik ikatan mawar kecil.Bila ikatan - ikatan tersebut dipasang sejajar, maka pola yang dihasilkan berupa lingkaran yang seragam.

\section{2). Alat dan Bahan Pembuatan Kain Ikat Celup}

Alat: spatula, panci, dan kompor. Bahan: kain, kelereng, plastik, karet gelang, dan daun jambu biji.

\section{Pengertian Pewarnaan Alami}

Zat pewarna alami merupakan zat pewarna yang berasal dari tanaman, buah, kulit, biji, dan bunga."Umumnya pewarna alami aman untuk digunakan dalam jumlah yang besar sekalipun, berbeda dengan pewarna sistetis yang keamanan penggunaannya harus dibatasi. Pewarna alami adalah pemberian permanen. Pada umumnya pewarnaan terdiri dari melarutkan zat warna dalam air kemudian bahan tekstil dimasukkan dengan larutan tersebut sehingga terjadi penyerapan zat warna kedalam serat.

\section{1). Istilah Warna Alami}

Menurut Djoemena, (2002 : 19) bahwa warna-warna dari pewarna alami dapat diperoleh dari tanaman atau akar pohon, akar-akar dan daun, antara lain: 1). Warna Biru disebut dengan istilah tarum, nilai ataupun indigo, didapat dari sejumlah daun beserta rantingnya direndam untuk beberapa hari, dicampur dengan berbagai jenis bahan penolong untuk kemudian disaring dipakai sebagai pewarna, 2). Warna hitam diperoleh dari kayu hitam yang ditumbuk. Adapula dengan cara direndam dalam lumpur hitam, 3). Warna merah didapat dari akar pohon mengkudu yang ditumbuk dan kemudian direndam dengan berbagai bahan penolong, 4). Warna sogam atau cokelat dapat diperoleh dari kulit pohon tinggi untuk warna cokelat muda hingga warna cokelat tua, 5). Warna cokelat kemerahan didapat dari daun kayu jati dan warna cokelat kusam di dapat dari kayu pohon pinang, kayu tinggi, dan daun teh, 6). Warna kuning didapat dari tanaman kunyit dan daun sejenis pohon kunyit, serta dari kulit kayu pohon mangga dan pohon nangka, 7). Warna hijau kecokelatan didapat dari daun jambu biji.

\section{Pengertian Daun Jambu Biji}

Menurut Cahyono (2010: 1) Jambu biji merupakan salah satu tanaman buah jenis perdu. Jambu biji dalam
Gorga : Jurnal Seni Rupa

Volume 09 Nomor 02 Juli-Desember 2020 p-ISSN: 2301-5942 | e-ISSN: 2580-2380

bahasa Inggris disebut Lambo guava. Tanaman ini berasal dari Brazilia Amerika Tengah, yang kemudian menyebar ke Thailand kemudian ke negara Asia lainnya seperti Indonesia. Hingga saat ini telah dibudidayakan dan menyebar luas di daerah-daerah Jawa. Jambu biji sering disebut juga jambu klutuk, jambu siki, atau jambu batu. Jambu tersebut kemudian dilakukan persilangan melalui stek atau okulasi dengan jenis yang lain, sehingga akhirnya mendapatkan hasil yang lebih besar dengan keadaan biji yang lebih sedikit bahkan tidak berbiji yang diberi nama jambu Bangkok karena proses terjadinya dari Bangkok.

Daun jambu biji (Psidium guajava L.) berbau aromatik dan rasanya sepat. Daunnya merupakan daun tunggal yang berwarna hijau keabuan, helai-helai daun berbentuk jorong sampai bulat memanjang, ujung daunnya meruncing sedangkan pangkal daunnya juga meruncing tetapi ada pula yang membulat, daun berukuran panjang antara $6 \mathrm{~cm}$ sampai $15 \mathrm{~cm}$ dan lebar antara $3 \mathrm{~cm}$ sampai $7,5 \mathrm{~cm}$ sedangkan tangkainya kurang lebih $1 \mathrm{~cm}$. Daun berambut penutup pendek, tampak berbintik-bintik yang sesungguhnya merupakan rongga-rongga lisigen, warnanya gelap namun biladalam keadaan terendam air menjadi tembus cahaya.

\section{METODE PENELITIAN}

Metode penelitian yang digunakan yaitu metode penelitian deskriptif kualitatif. Teknik pengumpulan data yang digunakan observasi, dokumentasi, dan wawancara. Instrumen peneltian yang digunkan yaitu catatan report, kamera, laptop, buku pedoman, wawancara dan daftar pertanyaan. Teknik analisis data yang digunakan yaitu deskriptif kualitatif.

\section{HASIL DAN PEMBAHASAN}

1.Hasil

1). Pengaruh Hasil Warna, Motif Dan Warna Dasar Kain Pada Hasil Teknik Ikat Celup Pada Perendaman Daun Jambu Biji Selama 1 Jam Dan Perendaman Kain Blacu Selama 2 Jam 


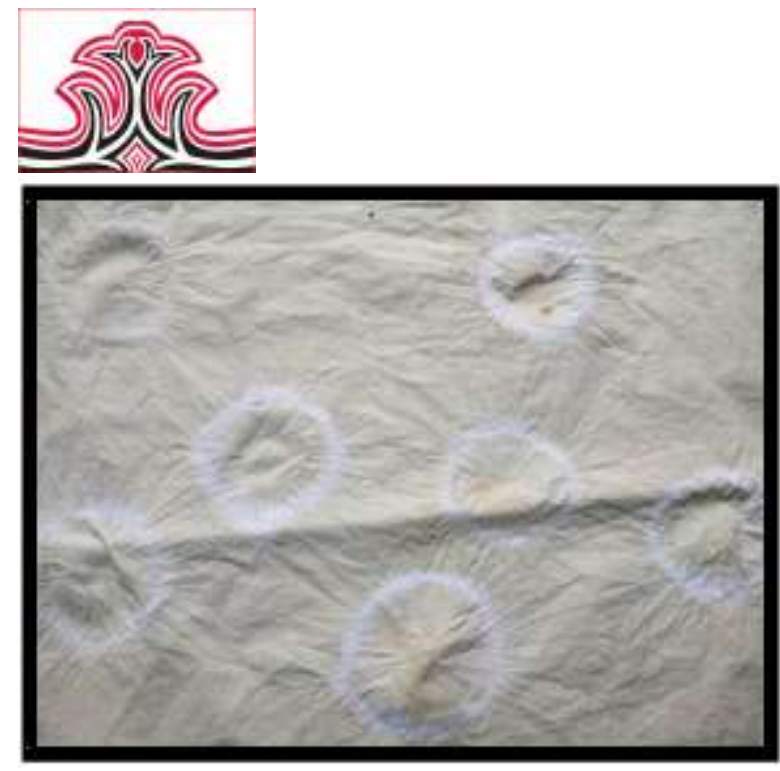

Gambar 1. Hasil Perendaman Daun Jambu Biji Selama 1 Jam Dan Pewarnaan Daun Jambu Biji Pada Kain Blacu Selama 2 Jam (Sumber: Ebid, 2020)

Berdasarkan hasil eksperimen yang telah dilakukan oleh penulis, diketahui bahwa tidak ada pengaruh hasil warna pada hasil perendaman daun jambu biji selama 1 jam untuk perendaman kain blacu selama 2 jam. Berdasarkan hasil pengamatan secara visual bahwa hasil warna yang dihasilkan hijau muda dan kurang cerah, hasil motif terbentuk kurang jelas dan kurang terang, tidak terbentuk motif bru pada kain.

\section{2). Pengaruh Hasil Warna, Motif Dan Warna Dasar Kain Pada Hasil Teknik Ikat Celup Pada Perendaman Daun Jambu Biji Selama 1 Jam Dan Perendaman Kain Blacu Selama 4 Jam}

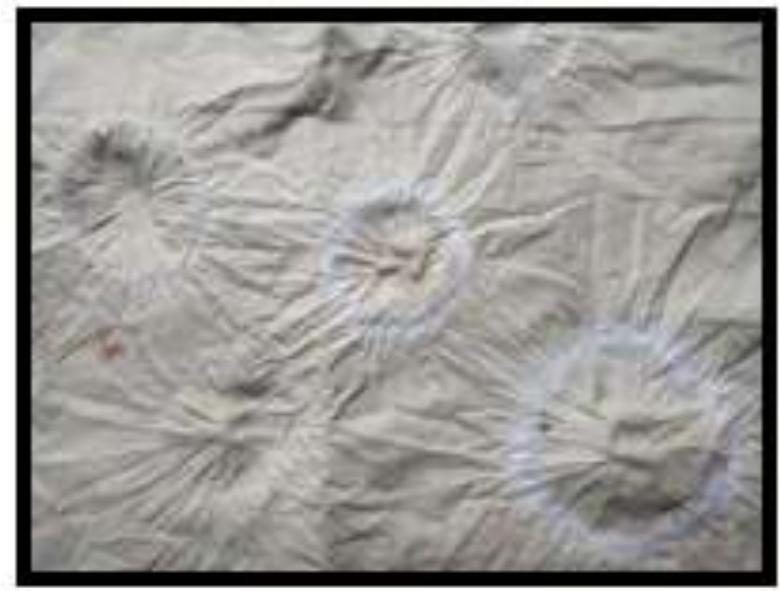

Gambar 2. Hasil Perendaman Daun Jambu Biji Selama 1 Jam Dan Pewarnaan DaunJambu Biji Pada Kain Blacu Selama 4 Jam (Sumber: Ebid, 2020)

Berdasarkan hasil eksperimen yang telah dilakukan oleh penulis, diketahui bahwa tidak ada pengaruh hasil warna pada hasil perendaman daun jambu biji selama 2 jam untuk perendaman kain blacu selama 4 jam. Berdasarkan hasil pengamatan secara visual bahwa hasil warna yang dihasilkan hijau muda dan kurang cerah, hasil motif terbentuk kurang jelas dan kurang terang, tidak terbentuk motif baru pada kain.
Gorga : Jurnal Seni Rupa

Volume 09 Nomor 02 Juli-Desember 2020

p-ISSN: 2301-5942 | e-ISSN: 2580-2380

3). Pengaruh Hasil Warna, Motif Dan Warna Dasar Kain Pada Hasil Teknik Ikat Celup Pada Perendaman Daun Jambu Biji Selama 1 Jam Dan Perendaman Kain Blacu Selama 6 Jam

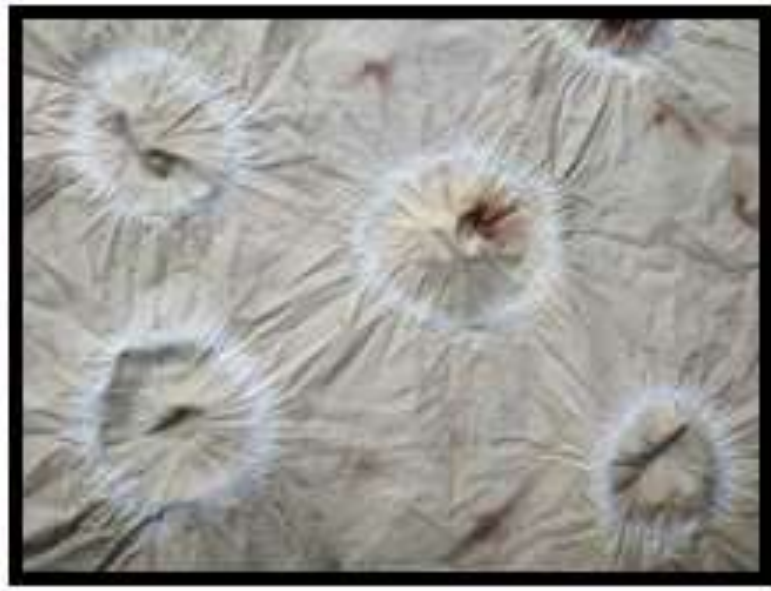

Gambar 3. Hasil Perendaman Daun Jambu Biji Selama 1 Jam Dan Pewarnaan DaunJambu Biji Pada Kain Blacu Selama 6 Jam (Sumber: Ebid, 2020)

Berdasarkan hasil eksperimen yang telah dilakukan oleh penulis, diketahui bahwa tidak ada pengaruh hasil warna pada hasil perendaman daun jambu biji selama 2 jam untuk perendaman kain blacu selama 6 jam. Berdasarkan hasil pengamatan secara visual bahwa hasil warna yang dihasilkan hijau muda dan kurang cerah, hasil motif terbentuk kurang jelas dan kurang terang, tidak terbentuk motif baru pada kain.

4). Pengaruh Hasil Warna, Motif Dan Warna Dasar Kain Pada Hasil Teknik Ikat Celup Pada Perendaman Daun Jambu Biji Selama 2 Jam Dan Perendaman Kain Blacu Selama 2 Jam

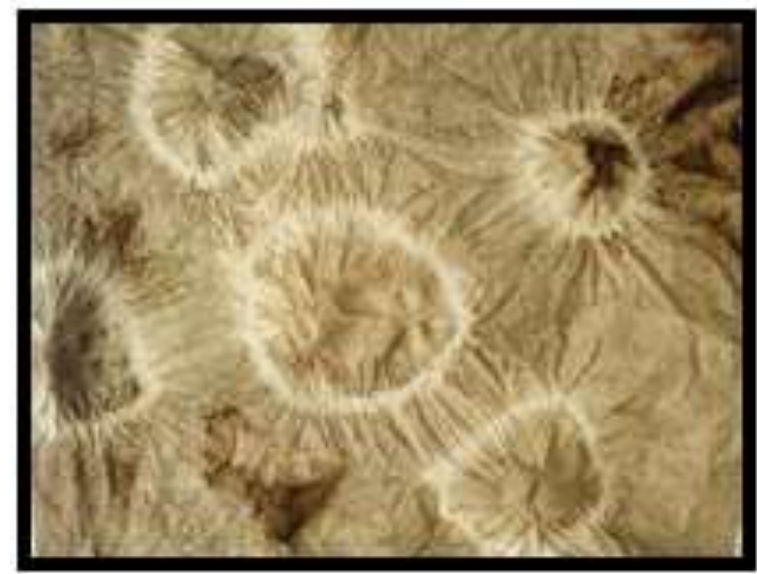

Gambar 4. Hasil Perendaman Daun Jambu Biji Selama 2 Jam Dan Pewarnaan Daun Jambu Biji Pada Kain Blacu Selama 2 Jam (Sumber: Ebid, 2020)

Berdasarkan hasil eksperimen yang telah dilakukan oleh penulis, diketahui bahwa ada pengaruh hasil warna pada hasil perendaman daun jambu biji selama 2 jam untuk perendaman kain blacu selama 2 jam. Berdasarkan hasil pengamatan secara visual bahwa 
hasil warna yang dihasilkan hijau kekuningan dan kurang cerah, hasil motif terbentuk kurang jelas dan kurang terang, dan terbentuk motif baru pada kain.

\section{5). Pengaruh Hasil Warna, Motif Dan Warna Dasar Kain Pada Hasil Teknik Ikat Celup Pada Perendaman Daun Jambu Biji Selama 2 Jam Dan Perendaman Kain Blacu Selama 4 Jam}

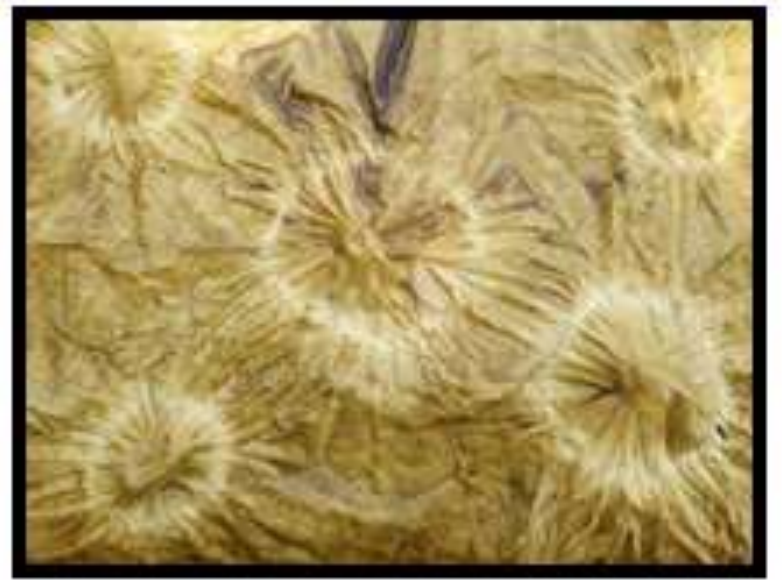

Gambar 5. Hasil Perendaman Daun Jambu Biji Selama 2 Jam Dan Pewarnaan DaunJambu Biji Pada Kain Blacu Selama 4 Jam (Sumber: Ebid, 2020)

Berdasarkan hasil eksperimen yang telah dilakukan oleh penulis, diketahui bahwa ada pengaruh hasil warna pada hasil perendaman daun jambu biji selama 2 jam untuk perendaman kain blacu selama 4 jam. Berdasarkan hasil pengamatan secara visual bahwa hasil warna yang dihasilkan hijau kekuningan dan kurang cerah, hasil motif terbentuk kurang jelas dan kurang terang, dan tidak terbentuk motif baru pada kain.

\section{Pembahasan}

Dapat dilihat perendaman daun jambu biji selama 1 jam dan perendaman kain blacu selama 2 jam, tidak terdapat pengaruh warna pada teknik ikat celup, kemudian untuk perendaman daun jambu biji selama 1 jam dan perendaman kain blacu selama 4 jam, tidak terdapat pengaruh warna pada teknik ikat celup, selanjutnya untuk perendaman daun jambu biji selama 1 jam dan perendaman kain blacu selama 6 jam menunjukkan hal yang sama tidak terdapat perubahan warna pada teknik ikat celup. Kemudian untuk perendaman daun jambu biji selama 2 jam dan perendaman kain blacu selama 2 jam, terdapat pengaruh warna kurang pekat pada teknik ikat celup, selanjutnya untuk perendaman daun jambu biji selama 2 jam dan perendaman kain blacu selama 4 jam terdapat pengaruh warna kurang pekat pada teknik ikat celup, kemudian perendaman daun jambu biji selama 3 jam dan perendaman kain blacu selama 6 jam juga menunjukkan hal yang sama bahwa terdapat pengaruh warna kurang pekat pada teknik ikat celup.
Gorga : Jurnal Seni Rupa

Volume 09 Nomor 02 Juli-Desember 2020 p-ISSN: 2301-5942 | e-ISSN: 2580-2380

Kemudian untuk perendaman daun jambu biji selama 3 jam dan perendaman kain blacu selama 2 jam terdapat pengaruh warna kurang pekat pada teknik ikat celup, selanjutnya perendaman daun jambu biji selama 3 jam dan perendaman kain blacu selama 4 jam terdapat pengaruh warna yang pekat pada teknik ikat celup, dan untuk perendaman daun jambu biji selama 3 jam dan perendaman kain blacu selama 6 jam menunjukkan bahwa warna dapat diterima lebih pekat pada teknik ikat celup.

Hal ini tentunya menggambarkan bahwa semakin lama daun jambu biji direndam dalam rebusan maka akan memberi pengaruh warna disetiap lamanya perendaman kain dalam rebusan tersebut. Maka dapat disimpulkan bahwa terjadinya pengaruh warna disebabkan oleh lamanya perendaman daun jambu biji dalam air rebusan.

\section{KESIMPULAN DAN SARAN}

\section{Kesimpulan}

Berdasar Berdasarkan hasil penelitian yang telah diuraikan pada bab IV, maka dapat disimpulkan sebagai berikut: 1). Terdapat pengaruh pewarnaan perendaman dauyn jambu biji pada teknik ikat celup pada hasil perendaman daun jambu biji selama 3 jam untuk perendaman kain blacu selama 2 jam dimana warna yang dihasilkan hijau kekuningan dan cerah, hasil motif terbentuk lebih terang dan jelas, 2). Terdapat pengaruh pewarnaan perendaman dauyn jambu biji pada teknik ikat celup pada hasil perendaman daun jambu biji selama 3 jam untuk perendaman kain blacu selama 4 jam dimana warna yang dihasilkan hijau kekuningan dan cerah, hasil motif terbentuk lebih terang dan jelas, terbentuk motif baru pada dasar kain, 3). Terdapat pengaruh pewarnaan perendaman dauyn jambu biji pada teknik ikat celup pada hasil perendaman daun jambu biji selama 3 jam untuk perendaman kain blacu selama 6 jam dimana warna yang dihasilkan hijau kekuningan dan lebih gelap, hasil motif terbentuk lebih terang dan jelas, dan 4). Lamanya proses perendaman larutan daun jambu biji dapat menghasilkan gradasi atau nilai gelap terang warna, semakin lama perendaman daun jambu biji maka warna yang dihasilkan akan semakin gelap.

\section{Saran}

Berdasarkan kesimpulan tersebut di atas, maka sebagai tindak lanjut penelitian ini disarankan hal - hal sebagai berikut: 1). Diharapkan kepada masyarakat untuk mengembangkan dan melestarikan kebudayaan bangsa dengan teknik ikat elup, 2). Diharapkan kepada pembaca khususnya mahasiswa/i Jurusan Pendidikan Seni Rupa untuk dapat melanjutkan penelitian 
pengembangan teknik ikat celup, 3). Diharapkan untuk mahasiswa/i hendaknya dapat menggunakan atau memanfaatkan zat pewarna alami karna ramah lingkungan dan aman untuk kesehatan, dan 4). Sebagai bahan masukan kepada peneliti selanjutnya untuk dapat mengembangkan pemanfaatan bahan - bahan alami lainnya untuk menghasilkan warna yang lebih bervariasi dengan proses perendaman bahan alami yang lebih lama.

\section{DAFTAR RUJUKAN}

Cahyono, Bambang. (2010). Sukses Budidaya Jambu Bini Di Pekarangan Dan Perkebunan.

Yogyakarta: Andi Offset.

Djoemena, Nian. S. (2002) . Lukis Garis - Garis

Bertuah. Jakarta: Djambatan. 